\title{
Utilization of Phosphorus in Lactating Cows Fed Varying Amounts of Phosphorus and Forage
}

\author{
Z. Wu, ${ }^{\star}$ S. K. Tallam, ${ }^{\star}$ V. A. Ishler, ${ }^{*}$ and D. D. Archibald† \\ *Department of Dairy and Animal Science, and \\ †Department of Crop and Soil Sciences, \\ Pennsylvania State University, \\ University Park, PA 16802
}

\begin{abstract}
The objective of this study was to determine the effect of dietary forage proportion and $\mathrm{P}$ content on fecal $\mathrm{P}$ excretion. Four dietary treatments were formed in a 2 $\times 2$ factorial arrangement. The $\mathrm{P}$ content was 0.33 or $0.42 \%$, and the forage proportion was 48 or $58 \%$ on a dry matter (DM) basis. The neutral detergent fiber content was 27 and $30 \%$ for the low and high forage diets, respectively. The $\mathrm{P}$ amount was varied by using monosodium phosphate, and the forage amount by changing the proportions of alfalfa silage and corn. The diets were fed to 44 midlactation Holsteins for $14 \mathrm{wk}$. Fecal $\mathrm{P}$ excretion was estimated using $\mathrm{Cr}$ marker and grab sampling. Dietary $\mathrm{P}$ content did not affect DM intake, milk yield, or milk composition. The $\mathrm{P}$ intake averaged 74 and $96 \mathrm{~g} / \mathrm{d}$ and fecal $\mathrm{P}$ averaged 0.69 and $0.92 \%$ (DM basis) or 49 and $65 \mathrm{~g} / \mathrm{d}$ for the low and high $\mathrm{P}$ diets, respectively. Thus, reducing dietary $\mathrm{P}$ from 0.42 to $0.33 \%$ resulted in approximately $25 \%$ less estimated fecal $\mathrm{P}$ excretion. Increasing dietary forage reduced milk yield ( 34.0 vs. $36.5 \mathrm{~kg} / \mathrm{d})$, but increased milk fat content (3.66 vs. 3.25\%). Estimated apparent digestibility of $\mathrm{P}$ tended to decrease ( $31.1 \mathrm{vs.} 36.6 \%$ ) when the forage proportion increased, but most of the change occurred when the diets contained the low amount of P. Overall, the effect of forage proportion on estimated fecal $P$ excretion was small when diets contained 48 or $58 \%$ forage, varied by alfalfa silage. Phosphorus intake has a much larger impact on fecal $\mathrm{P}$ excretion than forage proportion, and it does not seem necessary to adjust the dietary $\mathrm{P}$ content according to the forage proportion to provide the same amount of absorbed P. (Key words: phosphorus requirement, phosphorus excretion, forage, dairy cow)
\end{abstract}

Abbreviation key: HPHF = high $\mathrm{P}$, high forage; HPLF = high $\mathrm{P}$, low forage; $\mathbf{L P H F}=$ low $\mathrm{P}$, high forage;

Received November 26, 2002.

Accepted April 22, 2003.

Corresponding author: Z. Wu; e-mail: ziw1@psu.edu.
LPLF = low P, low forage; TCORN = Technical Committee on Responses to Nutrients.

\section{INTRODUCTION}

Although $\mathrm{P}$ has become the focus of nutrient management in the livestock industry, limited information is available on the utilization of $\mathrm{P}$ in the digestive tract of cattle. Until recently, the NRC (1989) has used a single $\mathrm{P}$ availability value for all feed sources. The 2001 NRC proposed separate values for different feed types, including $64 \%$ for forages, $70 \%$ for grains, and various values for inorganic mineral supplements. Although an availability value can provide a reference for the potential digestibility of $\mathrm{P}$ in a feed source, the absorption of $\mathrm{P}$ from a mixed diet may vary according to feeding conditions. Phosphorus intake reduced the apparent digestibility of $\mathrm{P}$ when $\mathrm{P}$ was fed above the requirement (Morse et al., 1992; Wu et al., 2000). Effects of other dietary factors are less known.

The recently revised NRC (2001) adopted the method developed by Spiekers et al. (1993) and the British Technical Committee on Responses to Nutrients (TCORN; 1991) to assess the maintenance requirement for P. In this method the $\mathrm{P}$ maintenance requirement is calculated as a function of DMI rather than BW, as done previously (NRC, 1989). This is related to the fact that the action of eating and rumination is associated with salivary secretion, which contains P. Measurements of salivary secretion reported include 11 to $14 \mathrm{~L} / \mathrm{kg}$ of DMI, 3.5 to $4.4 \mathrm{~L} / \mathrm{h}$ (Cassida and Stokes, 1986; Jacques et al., 1989), and $239 \pm 17 \mathrm{~L} / \mathrm{d}$ (Maekawa et al., 2002). Salivary P secretion can be substantial. Valk et al. (2002) reported an average salivary P concentration of $245 \mathrm{mg} / \mathrm{L}$ in cows fed $\mathrm{P}$ according to the requirement. Goff (1999) estimated that an amount of 30 to $90 \mathrm{~g}$ of $\mathrm{P}$ is secreted in saliva each day. It has also been estimated that up to $50 \%$ of the total $\mathrm{P}$ in the rumen or $80 \%$ of the endogenous $\mathrm{P}$ entering the gastrointestinal tract is contributed by saliva (Care, 1994).

Studies indicate that salivary $\mathrm{P}$ secretion can be affected by forage NDF content (Khorasani et al., 1997) 
and length of hay (Yano et al., 1991). Scott et al. (1995) suggested that the response in salivary $\mathrm{P}$ secretion to the form of the diet might be different at different $\mathrm{P}$ intakes. At $\mathrm{P}$ intakes above the requirement, a change from a finely ground diet to a coarse diet or from a concentrate diet to a roughage diet may increase fecal $\mathrm{P}$ excretion by stimulating salivation. At low $\mathrm{P}$ intakes, the impact of the physical nature of the diet would be smaller because an increase in saliva flow rate can be partially or entirely offset by a reduction in the concentration of $\mathrm{P}$ in saliva and an increase in reabsorption of $\mathrm{P}$ from the small intestine. According to this, $\mathrm{P}$ intake would play a part in the effect of forage on $\mathrm{P}$ utilization, in addition to its direct effect on $\mathrm{P}$ excretion.

The forage content of dairy rations can vary greatly. Typically, cows are fed a low forage diet in early lactation when milk production is high, and a high forage diet in late lactation when milk production is low. High forage diets may also be fed in herds with low production potentials, or when the profitability does not justify the use of a high concentrate diet. Because forage stimulates salivation and saliva contains phosphates, it is possible that the forage content of the diet has an impact on fecal $\mathrm{P}$ excretion. As producers have begun reducing the amount of $\mathrm{P}$ they feed, it is necessary to determine whether dietary $\mathrm{P}$ should be adjusted according to the forage content of the diet. The objective of this study was to determine the effect of dietary forage and $\mathrm{P}$ amounts on $\mathrm{P}$ utilization and excretion in lactating dairy cows.

\section{MATERIALS AND METHODS}

The experiment was conducted using a protocol that was approved by the Pennsylvania State University Institutional Animal Care and Use Committee. A completely randomized block design with a $2 \times 2$ factorial arrangement of treatments was utilized. The factors were dietary $\mathrm{P}$ amount and forage proportion, each having two levels. Their combinations formed the following four dietary treatments: low P, low forage (LPLF); low $\mathrm{P}$, high forage (LPHF); high P, low forage (HPLF); and high $\mathrm{P}$, high forage (HPHF). The $\mathrm{P}$ content of the diet was designed to be 0.38 or $0.48 \%$, and the forage proportion was 48 or $58 \%$, both on a DM basis. The low $\mathrm{P}$ diets (Table 1) contained no $\mathrm{P}$ supplement, and the high $\mathrm{P}$ diets were obtained by including $0.4 \%$ monosodium phosphate. Alfalfa silage was the major forage that was varied when formulating the low and high forage diets. Other forage sources used were alfalfa hay and corn silage. Steam-flaked corn (370 to $410 \mathrm{~g} / \mathrm{L}$; Pennfield Coop., Lancaster, PA) was the major grain source. This form was used to minimize starch fermentation in the hindgut based on the consideration that hindgut fer- mentation could result in microbial $\mathrm{P}$ excretion, which would interfere with the determination of the effect of forage on $\mathrm{P}$ excretion. Separate grain mixes (Agway Inc., Syracuse, NY) were prepared for the low forage diets and the high forage diets. The proportions of corn and the grain mixes in the diet were adjusted as the forage proportion changed. Based on the NRC (2001) tabular values, dietary $\mathrm{Ca}$ content was approximately $0.87 \%$ for all diets, and $\mathrm{NE}_{\mathrm{L}}$ averaged 1.70 and 1.66 $\mathrm{Mcal} / \mathrm{kg}$ for the low forage and high forage diets, respectively.

Forty-four multiparous Holsteins averaging 105 DIM ( $\mathrm{SD}=44)$ and $39 \mathrm{~kg} / \mathrm{d}$ of milk ( $\mathrm{SD}=7.0)$ were utilized in the experiment. The trial lasted 14 wk following a 2-wk adaptation period, during which all cows were fed a common herd diet. Cows were divided into 11 replicate blocks based on similarity in milk yield during the adaptation period and DIM. Cows within the blocks were randomly assigned to one of the four dietary treatments.

The animals were housed in a tie-stall barn and offered a TMR ad libitum at approximately $0800 \mathrm{~h}$ (5 to $10 \%$ refusal). The actual amounts of feed offered and refused by individual animals were recorded daily to obtain net intake. Milking was at 0500 and 1700 h; milk yields were recorded at each milking. Cows were weighed and scored for body condition (Wildman et al., 1982) after milking at the beginning and end of the treatment. Each BW was the average of the measurements on two consecutive days, and BCS was the average of two evaluators. Milk samples were collected weekly from two consecutive milkings. The samples were preserved with 2-bromo-2-nitropropane-1,3 diol (CAS\# 52-51-7), and analyzed by the Pennsylvania DHIA Laboratory (University Park, PA) for fat, protein, lactose, TS, and urea-N using infrared spectroscopy (Fossmatic 4000 Milko-Scan; Foss Electric, Hillerød, Denmark), and for SCC using a cell counter (Fossmatic 400; Foss Electric). The SNF content was calculated as TS minus fat.

Alfalfa hay, alfalfa silage, corn silage, steam-flaked corn, roasted soybeans, canola meal, and the grain mixes were sampled weekly. Orts were sampled daily from individual cows, then pooled by treatment and week. The DM content of the weekly samples was determined by air-drying in an oven at $55^{\circ} \mathrm{C}$ for $48 \mathrm{~h}$. Diet formulations (as-fed basis) were adjusted weekly for changes in DM content of the ingredients. Orts were used only for DMI calculation. The feed offered was regulated so as to leave no more than $10 \%$ orts. Impact of orts nutrient composition on nutrient intake was considered negligible. For example, the analysis of the $\mathrm{P}$ content of orts $(0.35$ and $0.45 \%$ for the low and high 
Table 1. Ingredient and nutrient content of diets (DM basis).

\begin{tabular}{|c|c|c|c|c|}
\hline \multirow[b]{2}{*}{ Item } & \multicolumn{4}{|c|}{ Dietary treatment ${ }^{1}$} \\
\hline & LPLF & LPHF & HPLF & $\mathrm{HPHF}$ \\
\hline & & & & \\
\hline \multicolumn{5}{|l|}{ Ingredient content } \\
\hline Alfalfa hay & 9.6 & 10.5 & 9.6 & 10.5 \\
\hline Alfalfa silage & 11.0 & 19.0 & 11.0 & 19.0 \\
\hline Corn silage & 27.4 & 28.5 & 27.4 & 28.5 \\
\hline Corn, steam-flaked & 28.5 & 20.5 & 28.1 & 20.1 \\
\hline Soybeans, roasted & 8.7 & 9.3 & 8.7 & 9.3 \\
\hline Canola meal & 5.7 & 4.7 & 5.7 & 4.7 \\
\hline Molasses, liquid & 3.5 & 3.5 & 3.5 & 3.5 \\
\hline $\mathrm{NaHCO}_{3}$ & 0.8 & 0.8 & 0.8 & 0.8 \\
\hline $\mathrm{NaH}_{2} \mathrm{PO}_{4}$ & - & - & 0.4 & 0.4 \\
\hline Grain mix $1^{2}$ & 4.8 & - & 4.8 & - \\
\hline Grain mix $2^{3}$ & - & 3.2 & - & 3.2 \\
\hline \multicolumn{5}{|l|}{ Nutrient content } \\
\hline $\mathrm{CP}$ & 18.0 & 18.2 & 18.0 & 18.1 \\
\hline $\mathrm{ADF}$ & 19.9 & 22.9 & 19.8 & 22.9 \\
\hline $\mathrm{NDF}$ & 27.1 & 30.3 & 27.1 & 30.3 \\
\hline Total P & 0.33 & 0.33 & 0.42 & 0.42 \\
\hline Available $\mathrm{P}^{4}$ & 0.23 & 0.22 & 0.31 & 0.30 \\
\hline \multicolumn{5}{|c|}{$\begin{array}{l}{ }^{1} \mathrm{LPLF}=\text { low } \mathrm{P}, \text { low forage; } \mathrm{LPHF}=\text { low } \mathrm{P} \text {, high forage; HPLF = high } \mathrm{P} \text {, low forage; and HPHF = high } \mathrm{P} \text {, } \\
\text { high forage. }\end{array}$} \\
\hline \multirow{4}{*}{\multicolumn{5}{|c|}{$\begin{array}{l}{ }^{2} \text { Grain mix } 1 \text { contained (DM basis): } 32.5 \% \text { an animal protein blend (Pro Base; Agway, Inc., Syracuse, } \\
\mathrm{NY} \text { ), } 3.7 \% \text { urea, } 28.6 \% \text { soybean meal }(48 \% \mathrm{CP} \text { ), and } 35.2 \% \text { mineral and vitamin supplements. Each kilogram } \\
\text { of the grain mix contained } 526 \mu \mathrm{g} \text { of } \mathrm{CP}, 83.1 \mathrm{~g} \text { of } \mathrm{Ca}, 5.2 \mathrm{~g} \text { of } \mathrm{P}, 29.1 \mathrm{~g} \text { of } \mathrm{Mg}, 9.5 \mathrm{~g} \text { of } \mathrm{K}, 35.5 \mathrm{~g} \text { of Na, } 53.3 \\
\mathrm{~g} \text { of } \mathrm{Cl}, 9.7 \mu \mathrm{g} \text { of } \mathrm{Co}, 300.0 \mu \mathrm{g} \text { of } \mathrm{Cu}, 723.0 \mu \mathrm{g} \text { of Fe, } 19.3 \mu \mathrm{g} \text { of } \mathrm{I}, 884.0 \mu \mathrm{g} \text { of } \mathrm{Mn}, 6.3 \mu \mathrm{g} \text { of Se, } 900.0 \mu \mathrm{g} \text { of } \\
\mathrm{Zn}, 145,000 \mathrm{IU} \text { of vitamin } \mathrm{A}, 36,000 \mathrm{IU} \text { of vitamin } \mathrm{D} \text {, and } 912 \mathrm{IU} \text { of vitamin } \mathrm{E} \text {. }\end{array}$}} \\
\hline & & & & \\
\hline & & & & \\
\hline & & & & \\
\hline \multirow{4}{*}{\multicolumn{5}{|c|}{$\begin{array}{l}{ }^{3} \mathrm{Grain} \text { mix } 2 \text { contained (DM basis): } 55.6 \% \text { an animal protein blend (Pro Base; Agway, Inc., Syracuse, } \\
\mathrm{NY} \text { ), and } 44.4 \% \text { mineral and vitamin supplements. Each kilogram of the grain mix contained } 449 \mathrm{~g} \text { of } \mathrm{CP} \text {, } \\
88.3 \mathrm{~g} \text { of } \mathrm{Ca}, 5.5 \mathrm{~g} \text { of } \mathrm{P}, 43.4 \mathrm{~g} \text { of } \mathrm{Mg}, 14.1 \mathrm{~g} \text { of } \mathrm{K}, 53.0 \mathrm{~g} \text { of Na, } 80.0 \mathrm{~g} \text { of Cl, } 14.5 \mu \mathrm{g} \text { of Co, } 448.0 \mu \mathrm{g} \mathrm{of} \mathrm{Cu} \text {, } \\
1080.0 \mathrm{~g} \text { of } \mathrm{Fe}, 28.8 \mu \mathrm{g} \text { of I, } 1320.0 \mu \mathrm{g} \text { of } \mathrm{Mn}, 9.4 \mu \mathrm{g} \text { of Se, } 1340.0 \mu \mathrm{g} \text { of } \mathrm{Zn}, 216,000 \mathrm{IU} \text { of vitamin A, } 54,000 \\
\mathrm{IU} \text { of vitamin D, and } 1,360 \mathrm{IU} \text { of vitamin E. }\end{array}$}} \\
\hline & & & & \\
\hline & & & & \\
\hline & & & & \\
\hline${ }^{4}$ Calculated using $\mathrm{F}$ & & & & \\
\hline
\end{tabular}

P groups, respectively) showed a negligible difference $(0.7 \%)$ from the calculated $\mathrm{P}$ intake results.

Nutrient digestibility was determined during the last $12 \mathrm{~d}$ of the experiment using the marker technique with Cr. Cows were dosed with $\mathrm{Cr}_{2} \mathrm{O}_{3}$ after each milking ( $5 \mathrm{~g} /$ dose or $10 \mathrm{~g} / \mathrm{d}$ ) via gelatin capsules. Feces were sampled from the rectum after each milking during the last $4 \mathrm{~d}$ of this period. This protocol resulted in eight samples for each cow. The eight samples were pooled and dried at $55^{\circ} \mathrm{C}$. A previous study (Wu et al., 2000) showed apparent variation in fecal $\mathrm{P}$ content during the day, particularly when the dietary $\mathrm{P}$ content was high $(0.48 \%)$; the variation appeared much smaller when dietary $\mathrm{P}$ was lower $(0.32$ and $0.40 \%$, similar to the amounts used in the present study). Nevertheless, the sampling protocol used in the present study may not have enabled as accurate estimation of fecal $P$ excretion as a more frequent schedule with varying times would.

All dried feed and fecal samples were ground through a Wiley mill (Arthur H. Thomas, Philadelphia, PA) with a 1-mm screen. After grinding, grain samples (steamflaked corn, roasted soybeans, canola meal, and the grain mixes) were further pooled to generate composite samples of every $4 \mathrm{wk}$. The composite grain samples, the weekly forage samples, and fecal samples were analyzed for DM $\left(102^{\circ} \mathrm{C}\right)$, CP using the Kjeldahl digestion system (Kjelter Tecator 2020; Höganäs, Sweden) and flow injection colorimetry (QuikChem method 15-10706-2-F, QuickChem FIA+ 8000 Series; Lachat Instruments, Milwaukee, WI) according to AOAC (1990), and $\mathrm{NDF}$ (heat stable $\alpha$-amylase and $\mathrm{Na}_{2} \mathrm{SO}_{3}$ were used) and ADF according to Robertson and Van Soest (1981); however, NDF and ADF were analyzed using only one composite for the grain samples. The ANKOM ${ }^{200}$ Fiber Analyzer incubator (ANKOM Technology, Fairport, NY) was used for NDF and ADF analyses. Fecal samples were analyzed for Cr by atomic absorption spectroscopy (Williams et al., 1962). Feed and fecal samples were analyzed for $\mathrm{P}$ using the preparation for Kjeldahl $\mathrm{N}$ by flow injection colorimetry (QuikChem method 15115-01-2-C, QuickChem FIA+ 8000 Series; Lachat Instruments). Certified commercial standards for $\mathrm{N}$ (LC17940-1) and P (LC18590-1) (LabChem Inc., Pitts- 
burgh, PA) were used to assure accuracy in the analyses using the flow injection colorimetry.

Chemical analyses of feeds and feces were based on DM measurements made at $102^{\circ} \mathrm{C}$. Nutrient content of the TMR was computed from the average nutrient content of the individual diet ingredients analyzed using the aforementioned composite samples. For molasses, the nutrient analyses supplied by the supplier (York Ag Products, Inc., York, PA) were used for the computation.

Two models were used for analyses of data with SAS (2000). Model 1 was used for DMI, milk yield, and milk composition by the mixed model procedure. Weekly averages of the measurements were used as repeated measures, for which a combination of autoregressive covariation on cow within dietary $\mathrm{P}$, forage, block, and random effect between animals was structured. For milk yield analysis, a covariate term was included in the models using the average milk yield obtained during the 2 -wk adaptation period. Repeated measures were not obtained for BW, BCS, and nutrient excretion. These variables were evaluated using model 2 by the general linear model procedure according to a completely randomized design. The two models are as follows:

$$
\begin{gathered}
\mathrm{Y}_{\mathrm{ijkl}}=\mu+\mathrm{B}_{\mathrm{i}}+\mathrm{P}_{\mathrm{j}}+\mathrm{F}_{\mathrm{k}}+\mathrm{W}_{\mathrm{l}}+(\mathrm{P} \times \mathrm{F})_{\mathrm{jk}}+ \\
(\mathrm{P} \times \mathrm{W})_{\mathrm{jl}}+(\mathrm{F} \times \mathrm{W})_{\mathrm{kl}}+(\mathrm{P} \times \mathrm{F} \times \mathrm{W})_{\mathrm{jkl}}+\mathrm{E}_{\mathrm{ijkl}} \\
\mathrm{Y}_{\mathrm{ijk}}=\mu+\mathrm{B}_{\mathrm{i}}+\mathrm{P}_{\mathrm{j}}+\mathrm{F}_{\mathrm{k}}+(\mathrm{P} \times \mathrm{F})_{\mathrm{jk}}+\mathrm{E}_{\mathrm{ijk}}
\end{gathered}
$$

where $\mathrm{Y}_{\mathrm{ijkl}}, \mathrm{Y}_{\mathrm{ijk}}=$ observation, $\mu=$ overall mean, $\mathrm{B}_{\mathrm{i}}=$ block effect, $\mathrm{P}_{\mathrm{j}}=$ dietary $\mathrm{P}$ amount effect, $\mathrm{F}_{\mathrm{k}}=$ dietary forage amount effect, $\mathrm{W}_{1}=$ week effect, $(\mathrm{P} \times \mathrm{F})_{\mathrm{jk}}=$ interaction between dietary $\mathrm{P}$ and forage amounts, $(\mathrm{P} \times \mathrm{W})_{\mathrm{j} 1}$ = interaction between dietary $\mathrm{P}$ amount and week, $(\mathrm{F}$ $\times \mathrm{W})_{\mathrm{kl}}=$ interaction between dietary forage amount and week, $(\mathrm{P} \times \mathrm{F} \times \mathrm{W})_{\mathrm{jkl}}=$ interaction among dietary $\mathrm{P}$, forage amounts, and week, and $\mathrm{E}_{\mathrm{ijk} k}, \mathrm{E}_{\mathrm{ijk}}=$ residual error.

Results are presented as least square means. Differences were considered significant at $P<0.05$ and as a trend at $P<0.10$, unless otherwise indicated.

\section{RESULTS AND DISCUSSION}

\section{Diet Composition}

Alfalfa hay was of medium quality based on the content of CP, NDF, and ADF (Table 2). The P content of alfalfa silage, corn, and soybeans was lower than the averages in the NRC (2001). Nutrient content of ingredients was relatively consistent during the experiment. Computed from ingredients, dietary ADF content was about 20 and $23 \%$, and NDF content 27 and $30 \%$, for the low forage and the high forage diets, respectively (Table 1). The total P content was 0.33 and $0.42 \%$ for the low and high $\mathrm{P}$ diets, respectively. The available $\mathrm{P}$ content was approximately 0.23 and $0.31 \%$, as estimated from the ingredients using the NRC (2001). Thus, the P availability was 68 and $72 \%$ for the two types of diets. The total $\mathrm{P}$ concentrations were lower than formulated $(0.38$ and $0.48 \%)$, but the treatments were clearly different. The dietary $\mathrm{P}$ requirement for the cows $(39 \mathrm{~kg} / \mathrm{d}$ of milk at the beginning of the trial) was $0.36 \%$ or $90 \mathrm{~g} / \mathrm{d}$; calculations were based on the NRC (2001) and used $25 \mathrm{~kg} / \mathrm{d}$ DMI. Therefore, $0.33 \%$ $\mathrm{P}$ was marginally sufficient ( $7 \mathrm{~g} / \mathrm{d}$ deficient), and $0.42 \%$ was excessive (15 g/d excess). According to a survey conducted in Pennsylvania in 2001 (Wu, 2003), dairy producers fed $0.39 \% \mathrm{P}$ for the low producing group and $0.44 \% \mathrm{P}$ for the high producing group of the herd on average. These levels were lower than the levels $(0.45$ to $0.50 \%$ ) obtained from surveys that were conducted a few years earlier (see Wu et al., 2001), suggesting that producers have reduced $\mathrm{P}$ recently. Accordingly, $0.42 \% \mathrm{P}$ was a good representative of the amount currently used by producers. The diets contained approximately $18 \% \mathrm{CP}, 37 \%$ of which was RUP based on the NRC (1989).

\section{Lactation Performance}

Dietary P amount did not significantly affect any of the lactation performance measurements (Table 3 ). Results are consistent with other studies (see $\mathrm{Wu}$ et al., 2000 ). These studies included comparisons of dietary $P$ of 0.33 and $0.39 \%, 0.35$ and $0.44 \%, 0.37$ and $0.55 \%, 0.38$ and $0.48 \%, 0.39$ and $0.65 \%$, and $0.34,0.51$, and $0.69 \%$. All of these comparisons showed no effect of $\mathrm{P}$ amount on milk production.

In contrast, Wu et al. (2000) showed that cows fed $0.31 \% \mathrm{P}$ performed normally during the first two-thirds of the lactation, but decreased milk yield during the last one-third of the lactation. Cows produced 11,000 $\mathrm{kg}$ of milk during the lactation or $36 \mathrm{~kg} / \mathrm{d}$ on average in that study. Similarly, reduced milk yields were reported when $0.24 \%$ was compared with 0.32 or $0.42 \% \mathrm{P}$ for cows milking $20 \mathrm{~kg} / \mathrm{d}$ (Call et al., 1987), $0.30 \%$ with $0.54 \% \mathrm{P}$ for cows milking $29 \mathrm{~kg} / \mathrm{d}$ (Kincaid et al., 1981), and 0.24 with 0.28 or $0.33 \% \mathrm{P}$ for cows milking $30 \mathrm{~kg} /$ d (Valk and Šebek, 1999). Calculated by the NRC (2001) using its DMI predictions and $67 \% \mathrm{P}$ availability for a 50:50 forage-to-concentrate diet that contains no mineral $\mathrm{P}$ source, the dietary $\mathrm{P}$ requirement for 20,30 , and $36 \mathrm{~kg} / \mathrm{d}$ of milk is at $0.29,0.33$, and $0.35 \% \mathrm{P}$, respectively. Clearly, the low $\mathrm{P}$ amount that resulted in a reduced milk yield in each of these studies was consider- 
Table 2. Analyses of dietary ingredients.

\begin{tabular}{|c|c|c|c|c|c|}
\hline Ingredient & $\mathrm{DM}$ & $\mathrm{CP}$ & NDF & $\mathrm{ADF}$ & $\mathrm{P}$ \\
\hline & & & $-(\%)$ & & 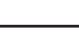 \\
\hline \multicolumn{6}{|c|}{ Alfalfa hay $(\mathrm{n}=15)$} \\
\hline Average & 89.1 & 18.1 & 48.9 & 44.3 & 0.237 \\
\hline SD & 1.3 & 1.4 & 2.5 & 2.6 & 0.012 \\
\hline \multicolumn{6}{|c|}{ Alfalfa silage $(\mathrm{n}=15)$} \\
\hline Average & 37.4 & 22.9 & 40.5 & 34.9 & 0.287 \\
\hline SD & 1.1 & 1.2 & 1.9 & 2.4 & 0.042 \\
\hline \multicolumn{6}{|c|}{ Corn silage $(\mathrm{n}=15)$} \\
\hline Average & 30.3 & 9.1 & 44.5 & 30.2 & 0.251 \\
\hline SD & 1.2 & 1.1 & 4.5 & 4.0 & 0.030 \\
\hline \multicolumn{6}{|c|}{ Corn, steam-flaked $(\mathrm{n}=4)$} \\
\hline Average & 86.6 & 9.9 & 8.3 & 3.3 & 0.235 \\
\hline SD & 0.8 & 0.7 & - & - & 0.046 \\
\hline \multicolumn{6}{|c|}{ Soybeans, roasted $(n=4)$} \\
\hline Average & 95.9 & 40.7 & 17.0 & 12.1 & 0.607 \\
\hline SD & 1.1 & 2.1 & - & - & 0.036 \\
\hline \multicolumn{6}{|c|}{ Canola meal $(\mathrm{n}=4)$} \\
\hline Average & 90.8 & 40.2 & 25.4 & 20.7 & 1.202 \\
\hline SD & 0.2 & 1.7 & - & - & 0.045 \\
\hline Molasses, liquid $^{1}$ & 6.0 & 4.0 & - & - & 0.130 \\
\hline \multicolumn{6}{|c|}{ Grain $\operatorname{mix} 1(\mathrm{n}=4)$} \\
\hline Average & 94.2 & 52.1 & 10.1 & 6.4 & 0.458 \\
\hline $\mathrm{SD}$ & 0.3 & 2.9 & - & - & 0.020 \\
\hline \multicolumn{6}{|c|}{ Grain mix $2(n=4)$} \\
\hline Average & 94.9 & 46.7 & 11.0 & 8.2 & 0.467 \\
\hline SD & 0.3 & 4.7 & - & - & 0.021 \\
\hline
\end{tabular}

${ }^{1}$ Nutrient content was provided by the supplier (York Ag Products, Inc., York, PA).

ably below the NRC calculated requirement. Cows used in the present study produced $35 \mathrm{~kg} / \mathrm{d}$ of milk on average, and consumed $23.5 \mathrm{~kg} / \mathrm{d}$ of DM. The requirement for these cows was calculated to be $55 \mathrm{~g} / \mathrm{d}$ for absorbed $\mathrm{P}$ or $82 \mathrm{~g} / \mathrm{d}$ total diet $\mathrm{P}(0.35 \%$ of the diet based on $67 \%$ $\mathrm{P}$ availability) according to the NRC (2001). The low P

Table 3. Performance of cows fed diets containing different amounts of phosphorus and forage.

\begin{tabular}{|c|c|c|c|c|c|c|c|c|}
\hline \multirow[b]{3}{*}{ Item } & \multicolumn{4}{|c|}{ Treatment $^{1}$} & \multirow[b]{3}{*}{ SEM } & \multirow{2}{*}{\multicolumn{3}{|c|}{$P^{2}$}} \\
\hline & \multirow{2}{*}{$\begin{array}{c}\text { LPLF } \\
(\mathrm{n}=11)\end{array}$} & \multirow{2}{*}{$\begin{array}{c}\text { LPHF } \\
(\mathrm{n}=11)\end{array}$} & \multirow{2}{*}{$\begin{array}{c}\text { HPLF } \\
(\mathrm{n}=11)\end{array}$} & \multirow{2}{*}{$\begin{array}{c}\text { HPHF } \\
(\mathrm{n}=11)\end{array}$} & & & & \\
\hline & & & & & & $\mathrm{P}$ & $\mathrm{F}$ & $\mathrm{P} \times \mathrm{F}$ \\
\hline DMI, kg/d & 23.1 & 24.0 & 23.2 & 23.9 & 0.5 & 0.96 & 0.09 & 0.92 \\
\hline Milk, kg/d & 36.4 & 33.8 & 36.5 & 34.2 & 1.1 & 0.83 & 0.03 & 0.90 \\
\hline \multicolumn{9}{|l|}{ Milk fat } \\
\hline$\%$ & 3.19 & 3.54 & 3.32 & 3.79 & 0.13 & 0.15 & 0.01 & 0.66 \\
\hline $\mathrm{kg} / \mathrm{d}$ & 1.176 & 1.196 & 1.212 & 1.285 & 0.066 & 0.35 & 0.49 & 0.69 \\
\hline $3.5 \% \mathrm{FCM}, \mathrm{kg} / \mathrm{d}$ & 35.0 & 34.0 & 35.3 & 35.6 & 1.5 & 0.55 & 0.81 & 0.69 \\
\hline \multicolumn{9}{|l|}{ Milk protein } \\
\hline$\%$ & 3.02 & 3.01 & 3.09 & 3.09 & 0.07 & 0.35 & 0.96 & 0.90 \\
\hline $\mathrm{Kg} / \mathrm{d}$ & 1.119 & 1.100 & 1.113 & 1.043 & 0.045 & 0.69 & 0.05 & 0.60 \\
\hline Milk lactose, \% & 4.64 & 4.47 & 4.68 & 4.71 & 0.09 & 0.15 & 0.49 & 0.28 \\
\hline Milk SCC, $1000 / \mathrm{ml}$ & 330 & 194 & 436 & 309 & 119 & 0.36 & 0.27 & 0.97 \\
\hline Milk urea N, mg/dl & 7.4 & 8.9 & 7.0 & 9.3 & 0.9 & 0.99 & 0.03 & 0.69 \\
\hline \multicolumn{9}{|l|}{ BW } \\
\hline Initial & 690 & 696 & 683 & 686 & 18 & 0.64 & 0.81 & 0.92 \\
\hline End & 722 & 744 & 708 & 717 & 21 & 0.34 & 0.47 & 0.77 \\
\hline Change & 0.386 & 0.566 & 0.296 & 0.376 & 0.103 & 0.18 & 0.22 & 0.63 \\
\hline \multicolumn{9}{|l|}{$\mathrm{BCS}^{3}$} \\
\hline Initial & 2.74 & 2.71 & 2.80 & 2.80 & 0.09 & 0.37 & 0.79 & 0.90 \\
\hline End & 2.98 & 2.91 & 2.92 & 2.89 & 0.11 & 0.73 & 0.66 & 0.88 \\
\hline Change & 0.24 & 0.21 & 0.11 & 0.09 & 0.06 & 0.07 & 0.66 & 0.92 \\
\hline
\end{tabular}

${ }^{1} \mathrm{LPLF}=$ Low P, low forage; LPHF = Low P, high forage; HPLF = High P, low forage; HPHF = High P, high forage.

${ }^{2} \mathrm{P}=\mathrm{P}$ level; $\mathrm{F}=$ forage level; $\mathrm{P} \times \mathrm{F}=\mathrm{P}$ level and forage level interaction.

${ }^{3}$ Obtained using a scale of $1=$ thin to $5=$ fat. 
Table 4. Apparent digestibilities of nutrients in cows fed diets containing different amounts of phosphorus and forage.

\begin{tabular}{|c|c|c|c|c|c|c|c|c|}
\hline \multirow[b]{3}{*}{ Item } & \multicolumn{4}{|c|}{ Treatment $^{1}$} & \multirow[b]{3}{*}{ SEM } & \multirow{2}{*}{\multicolumn{3}{|c|}{$P^{2}$}} \\
\hline & \multirow{2}{*}{$\begin{array}{l}\text { LPLF } \\
(\mathrm{n}=11]\end{array}$} & \multirow{2}{*}{$\begin{array}{l}\text { LPHF } \\
(\mathrm{n}=11)\end{array}$} & \multirow{2}{*}{$\begin{array}{l}\text { HPLF } \\
(\mathrm{n}=11)\end{array}$} & \multirow{2}{*}{$\begin{array}{l}\text { HPHF } \\
(\mathrm{n}=11)\end{array}$} & & & & \\
\hline & & & & & & $\mathrm{P}$ & $\mathrm{F}$ & $\mathrm{P} \times \mathrm{F}$ \\
\hline & & 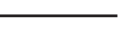 & & & & & & \\
\hline DM & 68.4 & 66.5 & 69.9 & 68.4 & 3.3 & 0.38 & 0.37 & 0.92 \\
\hline $\mathrm{CP}$ & 62.5 & 60.5 & 64.1 & 62.1 & 1.8 & 0.38 & 0.27 & 0.99 \\
\hline $\mathrm{ADF}$ & 49.9 & 48.3 & 53.6 & 53.8 & 3.2 & 0.16 & 0.83 & 0.79 \\
\hline $\mathrm{NDF}$ & 50.0 & 50.4 & 52.7 & 53.6 & 3.1 & 0.35 & 0.83 & 0.93 \\
\hline $\mathrm{P}$ & 38.7 & 30.7 & 34.4 & 31.4 & 3.3 & 0.60 & 0.10 & 0.45 \\
\hline
\end{tabular}

${ }^{1} \mathrm{LPLF}=$ Low $\mathrm{P}$, low forage; LPHF = Low P, high forage; HPLF = High P, low forage; HPHF = High P, high forage.

${ }^{2} \mathrm{P}=\mathrm{P}$ level; $\mathrm{F}=$ fiber level; $\mathrm{P} \times \mathrm{F}=\mathrm{P}$ level and forage level interaction.

amount fed was $75 \mathrm{~g} / \mathrm{d}$ or $0.33 \%$, and cows fed this amount of $\mathrm{P}$ performed essentially the same as those that received the higher amount. Together, these results support the NRC (2001) P requirement.

Increasing the dietary P amount from 0.33 to $42 \%$ had no effect on DMI or milk components. Whereas the dietary $\mathrm{P}$ amount did not affect $\mathrm{BW}$ change, $0.33 \% \mathrm{P}$ appeared to be associated with a higher BCS increase than $0.42 \% \mathrm{P}$, likely resulting from lower initial scores.

When forage was increased from 48 to $58 \%$, milk yield decreased by $2.5 \mathrm{~kg} / \mathrm{d}$ on average (Table 3). The observation was typical, and consistent with the literature. Reductions in milk yield were reported when the forage proportion of the diet was increased from 44 to $67 \%$ (Voelker et al., 2002) and from 35 to $65 \%$ (Beauchemin et al., 1994). Milk fat content increased, but fat yield or $3.5 \%$ FCM was not affected. Milk protein yield was slightly lower as a result of reduced milk yield. The effects on milk fat content and protein yield also are consistent with those reported previously (Voelker et al., 2002). Milk lactose and SCC were not affected by dietary forage treatments. Milk urea $\mathrm{N}$ concentration was higher in cows fed the low forage diets than in cows fed the high forage diets. The increase may be attributable to lower capture of ammonia into microbial protein in the rumen due to less fermentable carbohydrate. Unutilized ammonia would be absorbed and converted into urea in the liver, leading to elevated urea $\mathrm{N}$ concentrations in blood plasma and milk. Overall, the milk urea $\mathrm{N}$ concentrations for all forage treatments were low compared with the averages reported for dairy farms (Jonker et al., 2002), likely reflecting the use of steam-flaked corn. There was a tendency for higher DMI for the high forage diets than for the low forage diets, but the difference was small. Changing the forage proportion did not affect BW or BCS. An interaction between dietary $\mathrm{P}$ and forage amounts was not observed for any of the performance measurements.

\section{Nutrient Digestibility}

Variations in measurements of apparent digestibility were large (Table 4). Differences in stage of lactation and feed intake and the use of a digesta marker coupled with fixed sampling times all might have contributed to the variability. The digestibility of DM ranged from 67 to $70 \%$, ADF from 48 to $54 \%$, and NDF from 50 to $54 \%$. The values for ADF and NDF were high. The low $\mathrm{P}$ diets had numerically lower digestibility values for $\mathrm{DM}, \mathrm{CP}, \mathrm{ADF}$, and NDF, but the differences were not significant. Overall, there was no significant effect of dietary $\mathrm{P}$ amount on $\mathrm{P}$ apparent digestibility, because the values at high forage were very similar. Apparent digestibility of $\mathrm{P}$ has been shown to decrease when $\mathrm{P}$ is fed above the requirement (Morse et al., 1992; Wu et al., 2000).

One would expect lower DM digestibility with the high forage diets, but the difference in this case was not significant. The digestibility of $\mathrm{CP}$ had a similar pattern as DM, with no difference between forage treatments. Similarly, the digestibilities of ADF and NDF were not affected by dietary forage amount. Voelker et al. (2002) reported decreased NDF digestibility when the forage proportion of the diet was increased from 44 to $67 \%$; alfalfa and corn silage were the forage source. It was possible that the change from 48 to $58 \%$ forage in the current study was not large enough to cause a change in NDF digestibility. The apparent digestibility of $\mathrm{P}$ tended to be higher with $48 \%$ forage than $58 \%$ forage, averaging 36.6 and $31.1 \%$, respectively. However, most of the change occurred when the diets contained the low amount of $\mathrm{P}$. Phosphorus net absorption is considered to increase in response to increased $\mathrm{P}$ demands (Goff, 1999; TCORN, 1991). The increased apparent digestibility of $\mathrm{P}$ with low forage in the present study seems to agree with this observation, as cows fed the low forage diets produced more milk. 
WU ET AL.

Table 5. Estimated P excretion in cows fed diets containing different amounts of phosphorus and forage.

\begin{tabular}{|c|c|c|c|c|c|c|c|c|}
\hline \multirow[b]{3}{*}{ Item } & \multicolumn{4}{|c|}{ Treatment $^{1}$} & \multirow[b]{3}{*}{ SEM } & \multirow{2}{*}{\multicolumn{3}{|c|}{$P^{2}$}} \\
\hline & LPLF & LPHF & HPLF & HPHF & & & & \\
\hline & $(\mathrm{n}=11)$ & $(\mathrm{n}=11)$ & $(\mathrm{n}=11)$ & $(\mathrm{n}=11)$ & & $\mathrm{P}$ & $\mathrm{F}$ & $\mathrm{P} \times \mathrm{F}$ \\
\hline Intake, $\mathrm{g} / \mathrm{d}$ & 73.8 & 74.8 & 95.8 & 95.7 & 3.3 & 0.01 & 0.89 & 0.88 \\
\hline Fecal content, \% & 0.67 & 0.71 & 0.93 & 0.92 & 0.03 & 0.01 & 0.52 & 0.46 \\
\hline Fecal excretion, g/d & 45.2 & 52.2 & 63.7 & 66.0 & 4.0 & 0.01 & 0.25 & 0.56 \\
\hline Absorption, g/d & 28.6 & 22.5 & 32.1 & 29.7 & 2.9 & 0.07 & 0.15 & 0.51 \\
\hline
\end{tabular}

\section{Phosphorus Excretion}

Dietary $\mathrm{P}$ amount had a significant effect on fecal $\mathrm{P}$ content and on estimated fecal $\mathrm{P}$ excretion and $\mathrm{P}$ absorption (Table 5). Fecal $\mathrm{P}$ content averaged 0.69 and $0.92 \%$, and the estimated fecal $\mathrm{P}$ excretion averaged 49 and $65 \mathrm{~g} / \mathrm{d}$ for the low and high $\mathrm{P}$ diets, respectively, about $25 \%$ lower in each case for the low $\mathrm{P}$ diets. The reduction is consistent with those measured in other studies (Wu et al., 2000, 2001). Estimated net absorption of $\mathrm{P}$ was about $5.4 \mathrm{~g} / \mathrm{d}$ more for the high $\mathrm{P}$ diets than for the low $\mathrm{P}$ diets on average, which was small compared with the difference in intake $(21.5 \mathrm{~g} / \mathrm{d})$. Increased absorption is consistent with the hypothesis that some passive absorption of $\mathrm{P}$ occurs when $\mathrm{P}$ is provided in exceeding amounts relative to the requirement (NRC, 2001). Assuming that the P intake from the low $\mathrm{P}$ diets was just sufficient to meet the requirement, the rate of passive absorption would be $25 \%$ based on the $5.4 \mathrm{~g} / \mathrm{d}$ difference in net absorption and $21.5 \mathrm{~g} /$ $\mathrm{d}$ difference in intake. Challa and Braithwaite (1988) showed that calves (140 kg BW) absorbed more $\mathrm{P}$ when the $\mathrm{P}$ allowance was increased from 2.5 to 6 and $10 \mathrm{~g} /$ $\mathrm{d}$. However, only part of the additional $\mathrm{P}$ absorbed was retained, while the remainder was excreted in urine and feces as endogenous secretion. In the present study, estimated milk $\mathrm{P}$ secretion during the digesta collection period was not affected by dietary $\mathrm{P}$ intake. Conceivably, some of the additional $\mathrm{P}$ absorbed could be excreted in urine. Whereas generally small and variable, urinary $\mathrm{P}$ has been found to increase with $\mathrm{P}$ intake (Wu et al., 2000; Knowlton and Herbein, 2002).

Dietary forage amount did not affect fecal P content or estimated $\mathrm{P}$ absorption. Increasing the forage proportion from 48 to $58 \%$ appeared to reduce estimated $\mathrm{P}$ absorption, especially when the low $\mathrm{P}$ diets were fed, but the differences was not significant. The British TCORN (1991) cited data showing that feeding hay to sheep in a chopped form increased endogenous fecal $\mathrm{P}$ excretion compared to a finely ground, pelleted form when the diets were supplemented with inorganic $\mathrm{P}$, but the form of the diet did not make a difference when no $\mathrm{P}$ supplementation was made.

The major objective of this study was to determine the effect of dietary forage content on $\mathrm{P}$ utilization and its interaction with dietary $\mathrm{P}$ amount. Overall, changing the forage proportion of the diet from 48 to $58 \%$ had little effect on estimated $\mathrm{P}$ excretion. Khorasani et al. (1997) fed alfalfa, barley, oats, or triticale silages to lactating dairy cows at 50\% of the diet. Duodenal flow of $\mathrm{P}$ increased compared to $\mathrm{P}$ intakes for all of the diets, indicating salivary $\mathrm{P}$ contributions, but the increase was larger with the cereal grain silages than with alfalfa silage, coinciding with the NDF content of the forage sources. Yano et al. (1991) showed increased salivary $\mathrm{P}$ contributions to the duodenal $\mathrm{P}$ flow in sheep when long hay was fed compared to short hay. The British TCORN (1991) showed similar data, demonstrating that fecal endogenous $\mathrm{P}$ excreted by sheep increased when the proportion of hay in the diet increased or when hay was fed in a loose form compared with a pelleted form. In contrast, Ternouth (1989) reported that sheep fed chopped straw excreted less endogenous $P$ in feces than those fed ground straw.

Although it was undetermined how much saliva was increased when the dietary forage was changed from 48 to $58 \%$ in the current study, the total salivary secretion may have not changed greatly. It is true that salivation is affected by dietary forage source and amount through chewing activity. Mertens (1997) demonstrated that chewing is stimulated by effective fiber. Voelker et al. (2002) showed that the amount of time spent chewing increased with increasing dietary NDF content and forage particle size. However, Maekawa et al. (2002) recently suggested that the net increase in saliva secretion due to increased chewing time was not as great as often thought. In their study, saliva output was determined by difference in moisture of feed consumed and the masticate collected at the cardia through a fistula. Chewing time did increase when the proportion of barley silage in the diet was increased from 40 to 50 and $60 \%$, but the increase in chewing time was 
not associated with a similar increase in saliva volume. This occurred because the increase in saliva output due to increased chewing time was partially offset by decreased salivation during resting time. However, it was noted that the total saliva volume was considerably higher when cows were fed the highest silage diet than the lowest silage diet ( 255 vs. $230 \mathrm{~L} / \mathrm{d}$ ). Jacques et al. (1989) reported that total salivary secretion in cows increased when the hay content of the diet was increased from 50 to $90 \%$. Unquestionably, the magnitude of the difference in the forage proportion is important. In our study, the forage proportion was 48 or $58 \%$, and the NDF content was 27 or $30 \%$. The differences may not have been large enough to elicit a significant change in total saliva secretion. The similarity in the nutrient digestibilities measured would support this explanation. Also, had dry hay been used to vary the forage proportion rather than silage, the effect probably would have been larger.

The output of salivary $\mathrm{P}$ is further influenced by other factors. Whereas many studies have shown that salivary $\mathrm{P}$ secretion was related to salivation rate, as measured at the duodenum (Breves and Schroder, 1991), the total salivary $\mathrm{P}$ output may not necessarily increase even if salivary volume increases, because the concentration of $\mathrm{P}$ in saliva may decrease as the rate of salivation increases (Cohen, 1980). Salivary P content is related to blood plasma P concentrations (Care, 1994). Additionally, salivary $\mathrm{P}$ is absorbable in the small intestine. Coefficient values of 75 to $80 \%$ for salivary $\mathrm{P}$ absorption have been reported (Scott, 1988; Challa et al., 1989), but the efficiency of absorption can vary greatly (Scott et al., 1995).

The forage type, form, and particle size may influence the rate of salivation and salivary $\mathrm{P}$ concentration. For example, Tomas (1974) reported that the total secretion of $\mathrm{P}$ in saliva was higher in sheep fed long hay than pelleted or finely ground hay. Scott and Buchan (1987) reported that sheep fed hay excreted more $\mathrm{P}$ in feces than those fed grass, the hay diet comprising a higher proportion of coarser particles than the grass diet, resulting in more saliva and salivary $\mathrm{P}$ secretion. Scott (1988) showed increased fecal $\mathrm{P}$ of salivary origin in sheep when the particle size of the forage source fed was increased. However, Yano et al. (1991) showed that, whereas duodenal flow of $\mathrm{P}$ in sheep increased in response to the chop length of hay, the intestinally absorbed $\mathrm{P}$ also increased, resulting in no change in net secretion of $\mathrm{P}$.

The major factor that determines the amount of $\mathrm{P}$ excreted in saliva is $\mathrm{P}$ intake, as a high intake can trigger salivary $\mathrm{P}$ secretion as a mechanism of $\mathrm{P}$ homeostasis (McDowell, 1992). Unlike nonruminants, in which the major control of $\mathrm{P}$ homeostasis is through renal excretion, ruminants usually excrete very little $\mathrm{P}$ in urine due to the high reabsorptive capacity for $\mathrm{P}$ in the renal tubules (Cohen, 1980). Rather, they rely on salivary secretion for $\mathrm{P}$ homeostasis (Care, 1994). Ruminants can secrete $\mathrm{P}$ in saliva in much higher concentrations than in blood plasma, and reabsorption of $\mathrm{P}$ in the small intestine is regulated according to the need (Breves and Schroder, 1991; Scott, 1988; Care, 1994). When $P$ intake is in excess of the need, unwanted $\mathrm{P}$ is ultimately excreted in a regulated manner. Braithwaite (1985) suggested that regulated fecal $\mathrm{P}$ excretion increased in direct relation to increased $\mathrm{P}$ intake in lambs. Unavailable $P$, regulated $P$, and inevitable secretion $\mathrm{P}$ form the total $\mathrm{P}$ in feces (Spiekers et al., 1993).

In the present study, the estimated total $\mathrm{P}$ excretion in feces averaged 49 and $65 \mathrm{~g} / \mathrm{d}$ for the low and high $\mathrm{P}$ diets, respectively. Of these amounts, 24 and $27 \mathrm{~g} / \mathrm{d}$ would be from unavailable feed $\mathrm{P}$ (calculated from 74 and $96 \mathrm{~g} / \mathrm{d}$ of intake $\mathrm{P}$ with 68 and $72 \%$ availability). The remaining 25 and $38 \mathrm{~g} / \mathrm{d}$ would be composed of regulated $\mathrm{P}$ and inevitable $\mathrm{P}$. Applying the parameter measurements obtained in this study to the report of Wu et al. (2000; Table 8), the regulated $\mathrm{P}$ would be 4 and $19 \mathrm{~g} / \mathrm{d}$ for the 0.33 and $0.42 \% \mathrm{P}$ diets, respectively. Therefore, the inevitable P loss would be 21 and $19 \mathrm{~g} /$ $\mathrm{d}$. Dividing these values by $23.5 \mathrm{~kg} / \mathrm{d}$ of the average DMI (Table 3) would result in approximately $0.9 \mathrm{~g}$ of P per kilogram of DMI, which supports the NRC (2001) estimate of $1 \mathrm{~g} / \mathrm{kg}$ of DMI for the maintenance requirement of $P$.

\section{CONCLUSIONS}

Feeding diets that contained $0.33 \%$ compared with $0.42 \% \mathrm{P}$ to lactating dairy cows reduced estimated fecal $\mathrm{P}$ excretion by $25 \%$. Milk production was not affected. The low $\mathrm{P}$ amount was in close agreement with the NRC (2001) recommendations and represented a marginally sufficient amount for midlactation cows producing 35 $\mathrm{kg} / \mathrm{d}$ of milk. Increasing the dietary forage proportion from 48 to $58 \%$ by using alfalfa silage had little effect on estimated fecal $\mathrm{P}$ excretion. As these amounts encompass the normal range of the forage content of the diet in practical situations, results suggest that $P$ can be fed according to the NRC (2001) recommendations without being adjusted according to the forage proportion of the diet. Phosphorus intake has a much larger impact on fecal $\mathrm{P}$ excretion than dietary forage proportion.

\section{REFERENCES}

Association of Official Analytical Chemists. 1990. Official Methods of Analysis. Vol. I. 15th ed. AOAC, Arlington, VA. 
Beauchemin, K. A., B. I. Farr, L. M. Rode, and G. B. Schaalje. 1994. Effects of alfalfa silage chop length and supplementary long hay on chewing and milk production of dairy cows. J. Dairy Sci. 77:1326-1339.

Braithwaite, G. D. 1985. Endogenous faecal loss of phosphorus in growing lambs and the calculation of phosphorus requirements. J. Agric. Sci. (Camb.) 105:67-72.

Breves, G., and B. Schrŏder. 1991. Comparative aspects of gastrointestinal P metabolism. Nutr. Res. Rev. 4:125-140.

Call, J. W., J. E. Butcher, J. L. Shupe, R. C. Lamb, R. L. Boman, and A. E. Olson. 1987. Clinical effects of low dietary phosphorous concentrations in feed given to lactating dairy cows. Am. J. Vet. Res. 48:133-136.

Care, A. D. 1994. The absorption of phosphorus from the digestive tract of ruminant animals. Br. Vet. J. 150:197-205.

Cassida, K. A., and M. R. Stokes. 1986. Eating and resting salivation in early lactation dairy cows. J. Dairy Sci. 69:1282-1292.

Challa, J., and G. D. Braithwaite. 1988. Phosphorus and calcium metabolism in growing calves with special emphasis on phosphorus homeostasis. 1. Studies of the effect of change in the dietary phosphorus intake on phosphorus and calcium metabolism. J. Agric. Sci. (Camb.) 110:573-581.

Challa, J., G. D. Braithwaite, and M. S. Dhanoa. 1989. Phosphorus homoeostasis in growing calves. J. Agric. Sci. (Camb.) 112:217226.

Cohen, R. D. H. 1980. Phosphorus in rangeland ruminant nutrition: A review. Livest. Prod. Sci. 7:25-37.

Goff, J. P. 1999. Treatment of calcium, phosphorus, and magnesium balance disorders. Vet. Clin. North. Am. Food Anim. Prac. 15:619-639.

Jacques, K., D. L. Harmon, W. J. Croom, Jr., and W. M. Hagler, Jr. 1989. Estimating salivary flow and ruminal water balance of intake, diet, feeding pattern, and slaframine. J. Dairy Sci. $72: 443-452$

Jonker, J. S., R. A. Kohn, and J. High. 2002. Use of milk urea nitrogen to improve dairy diets. J. Dairy Sci. 85:939-946.

Khorasani, G. R., R. A. Janzen, W. B. McGill, and J. J. Kenelly. 1997. Site and extent of mineral absorption in lactating cows fed wholecrop cereal grain silage or alfalfa silage. J. Anim. Sci. 75:239-248.

Kincaid, R. L., J. K. Hillers, and J. D. Cronath. 1981. Calcium and phosphorus supplementation of rations for lactating cows. J. Dairy Sci. 64:754-758.

Knowlton, K. F., and J. H. Herbein. 2002. Phosphorus partitioning during early lactation in dairy cows fed diets varying in phosphorus content. J. Dairy Sci. 85:1227-1236.

Maekawa, M., K. A. Beauchemin, and D. A. Christensen. 2002. Effect of concentrate level and feeding management on chewing activities, saliva production, and ruminal $\mathrm{pH}$ of lactating dairy cows. J. Dairy Sci. 85:1165-1175.

McDowell, L. R. 1992. Minerals in Animal and Human Nutrition. Academic Press, Inc. Harcourt Brace Jovanovich, New York.

Mertens, D. R. 1997. Creating a system for meeting the fiber requirements of dairy cows. J. Dairy Sci. 80:1463-1481.

Morse, D., H. H. Head, C. J. Wilcox, H. H. Van Horn, C. D. Hissem, and B. Harris, Jr. 1992. Effects of concentration of dietary phosphorus on amount and route of excretion. J. Dairy Sci. 75:3039-3049.

National Research Council. 1989. Nutrient Requirements of Dairy Cattle. 6th rev. ed. Natl. Acad. Sci., Washington, DC.

National Research Council. 2001. Nutrient Requirements of Dairy Cattle. 7th rev. ed. Natl. Acad. Sci., Washington, DC.
Robertson, J. B., and P. J. Van Soest. 1981. Page 123 in The Analysis of Dietary Fiber in Foods. W. P. T. Kames and O. Theander, ed. Marcel Dekker Inc., New York.

SAS User's Guide: Statistics. 2000. Version 8 Edition. SAS Inst., Inc., Cary, NC.

Scott, D. 1988. Control of phosphorus balance in ruminants. Pages 156-174 in Aspects of Digestive Physiology in Ruminants: Proc. Satellite Symp. 30th Int. Congress Int. Union Physiol. Sci. Cornell Univ. A. Dobson and M. J. Dobson, ed. Comstock Publ. Assoc., Ithaca, NY.

Scott, D., and W. Buchan. 1987. The effects of feeding hay or grass diets on saliva phosphorus secretion, net intestinally phosphorus absorption and on the partition of phosphorus excretion between urine and faeces in the sheep. Q. J. Exp. Physiol. 72:331-338.

Scott, D., A. A. J. Rajaratne, and W. Buchan. 1995. Factors affecting faecal endogenous phosphorus loss in the sheep. J. Agric. Sci. 124:145-151.

Spiekers, H., R. Brintrup, M. Balmelli, and E. Pfeffer. 1993. Influence of dry matter intake on faecal phosphorus losses in dairy cows fed rations low in phosphorus. J. Anim. Physiol. Anim. Nutr. 69:37-43.

Technical Committee on Responses to Nutrients. 1991. Report 6: A reappraisal of the calcium and phosphorus requirements of sheep and cattle. Nutr. Abstr. Rev. (Ser. B) 61:573-612.

Ternouth, J. H. 1989. Endogenous losses of phosphorus by sheep. J. Agric. Sci. (Camb.) 113:291-297.

Tomas, F. M. 1974. Phosphorus homeostasis in sheep. II. Influence of diet on pathway of excretion of phosphorus. Aust. J. Agric. Res. $25: 485-493$

Valk, H., and L. B. J. S̆ebek. 1999. Influence of long-term feeding of limited amounts of phosphorus on dry matter intake, milk production, and body weight of dairy cows. J. Dairy Sci. 82:2157-2163.

Valk, H., L. B. J. Sebek, and A. C. Beynen. 2002. Influence of phosphorus intake on excretion and blood plasma and saliva concentrations of phosphorus in dairy cows. J. Dairy Sci. 85:2642-2649.

Voelker, J. A., G. M. Burato, and M. S. Allen. 2002. Effects of pretrial milk yield on responses of feed intake, digestion, and production to dietary forage concentration. J. Dairy Sci. 85:2650-2661.

Wildman, E. E., G. M. Jones, P. E. Wagner, R. L. Boman, H. F. Troutt, Jr., and T. N. Lesch. 1982. A dairy cow body condition scoring system and its relationship to selected production characteristics. J. Dairy Sci. 65:495-501.

Williams, C. H., D. J. Davis, and O. Iismaa. 1962. The determination of chromium oxide in faeces samples by atomic absorption spectrophotometry. J. Agric. Sci. (Camb.) 59:381-388.

Wu, Z. 2003. People still feed too much phosphorus. Hoard's Dairyman. March:210.

Wu, Z., L. D. Satter, A. J. Blohowiak, R. H. Stauffacher, and J. H. Wilson. 2001. Milk production, phosphorus excretion, and bone characteristics of dairy cows fed different amounts of phosphorus for two or three years. J. Dairy Sci. 84:1738-1748.

Wu, Z., L. D. Satter, and R. Soja. 2000. Milk production, reproductive performance, and fecal excretion of phosphorus by dairy cows fed three amounts of phosphorus. J. Dairy Sci. 83:1028-1041.

Yano, F., H. Yano, and G. Breves. 1991. Calcium and phosphorus metabolism in ruminants. Pages 277-295 in Physiological Aspects of Digestion and Metabolism in Ruminants: Proc. 7th Int. Symp. Ruminant Physiol. T. Tsuda, Y. Sasaki, and R. Kawashima, ed. Academic Press Inc., San Diego, CA. 